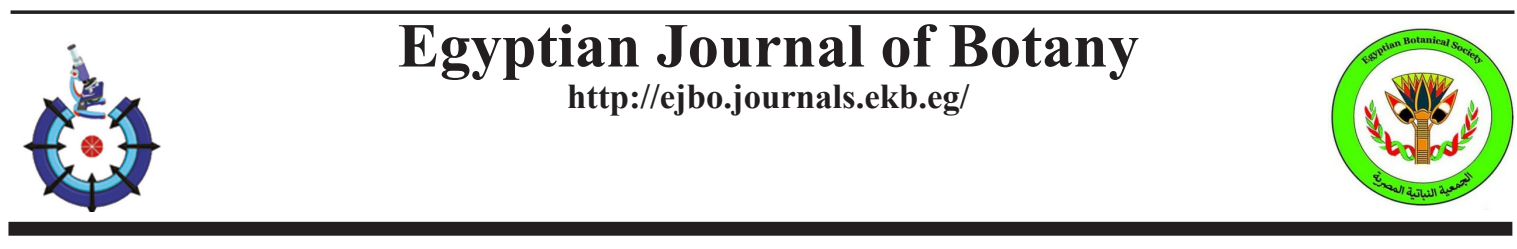

\title{
Phosphate Solubilization Potential of Rhizosphere Soil Bacteria and their Possible Use as Biofertilizers
}

Salwa Abdel Rahman ${ }^{(1) \#}$, Hoda Yusef ${ }^{(1)}$, Hassan Dhaini ${ }^{(2)}$

(1)Botany and Microbiology Department, Faculty of Science, Alexandria University, Alexandria, Egypt; ${ }^{(2)}$ Department of Biological Sciences, Faculty of Science, Beirut Arab University, Beirut, Lebanon.

\begin{abstract}
$\mathbf{P}$ HOSPHORUS is second only to Nitrogen as the most limiting element for plant growth. The concentration of soluble $\mathrm{P}$ in soil is usually very low, however, more than $80 \%$ of $\mathrm{P}$ becomes immobile and unavailable for plant uptake. The development of a biological alternative to chemical fertilizers is of great importance for the improvement of agriculture as well as the protection of the environment. The present study investigated thirteen efficient inorganicphosphate solubilizing bacteria (PSB) isolated from various rhizospheric soil samples collected from El-Bekaa, Lebanon. Two isolates (Pseudomonas sp. HD and Escherichia sp. HD), exhibited the highest phosphate solubilization percentages of 76.60 and $88.21 \%$, respectively. Application of the Plackett-Burman design resulted in phosphate solubilization efficiency of 79.08 and $93.77 \%$ for Pseudomonas sp. HD and Escherichia sp. HD, respectively. In vitro cultivation of different plants was applied to reflect the relative importance of Pseudomonas sp. HD and Escherichia sp. HD as biofertilizers on growth parameter of melon (Cucumis melo var. inodorus), horse-bean (Vicia faba), cucumber (Cucumis sativus), Armenian cucumber (Cucumis melo var. flexuosus), bean (Phaseolus vulgaris) and squash (Cucurbita pepo). The best growth parameters of the studied plants where observed where seeds were soaked in water and $\mathrm{Ca}_{3}\left(\mathrm{PO}_{4}\right)_{2}$ with Pseudomonas sp. $\mathrm{HD}$ and Escherichia sp. HD.
\end{abstract}

Keywords: Biofertilizers, Escherichia sp., HD, HD El-Bekaa, Lebanon, Phosphate solubilization, Pseudomonas sp.

\section{Introduction}

Phosphorus (P) is an essential element in the nutrition of plant. Phosphorus is extremely important as a structural part of many compounds included in photosynthesis, energy transfer, signal transduction, and respiration (Khan et al., 2010). P occurs in soil mainly as insoluble mineral complexes which are not available form for root uptake. Some of these complexes appearing after frequent application of chemical fertilizers (Rengel \& Marschner, 2005).

The extended use of chemical $\mathrm{P}$ fertilizers results in accumulation of harmful chemical residues, which may lead to serious environmental and health impacts (Tilman et al., 2001), therefore the search for environment friendly feasible alternative strategies for improving crop production in low or P-deficient soils is very important (Zaidi et al., 2009). Biofertilizers, are used to increase the fertility of soil, they help in promoting the growth of plants and trees by increasing the supply of essential nutrients to the plants. They are also responsible for continuous availability of nutrients from natural sources (Suhag, 2016).

Application of microbial biofertilizer is an important step in the biofertilizer technology.

"Corresponding author email: Salwam218@gmail.com Tel: 00201271862554

Received 17/11/2020; Accepted 8/5/ 2021

DOI: 10.21608/ejbo.2021.50174.1584

Edited by: Prof. Dr.: Khaled M. Ghanem, Department of Botany and Microbiology, Faculty of Science, Alexandria University, Alexandira, Egypt.

C2021 National Information and Documentation Center (NIDOC) 
Phosphate solubilizing organisms are widely spread in the environment; they can belong to bacteria, yeasts and molds in addition to algae. These beneficial organisms are able to convert organic and inorganic insoluble phosphorus compounds to soluble form that can easily be assimilated by plants. Several species of phosphate-solubilizing bacteria (PSB) have been identified including Pseudomonas sp. (Rodriguez \& Fraga, 1999; Sahandi et al., 2019), Bacillus (Ankit et al., 2011), Rhizobium (Halder \& Chakrabartty, 1993), Achromobacter, Aerobacter, Flavobacterium, Erwinia (Goldstein, 1986; Rodriguez \& Fraga 1999), Citrobacter, Enterobacter, Proteus, Serratia (Thaller et al., 1995; Farhat et al., 2009), Klebsiella (Ohtake et al., 1996), Rhizoctonia solani (Verma et al., 2014) and many other genera. It is well recognized that $\mathrm{PSB}$ produce organic acids (Halder et al., 1990). The second known organic acid identified in PSB is 2-ketogluconic acid, which is secreted by Rhizobium leguminosarum (Halder et al., 1990), Rhizobium meliloti (Halder \& Chakrabartty, 1993). Lactic, isovaleric, isobutyric and acetic acids were identified in Bacillus firmus (Banik \& Dey, 1982). PSB may act through mineralization of organic phosphorus and this is carried out by means of the action of several phosphatases which have the ability to mineralize organic phosphate (Rossolini et al., 1998). Some authors suggested the potential role of siderophores released from phosphate solubilizing microorganisms (Caballero-Mellado et al., 2007; Hamdali et al., 2008). According to $\mathrm{Yi}$ et al. (2008), exopolysaccharides (EPSs) excreted by some bacteria may have a role in P-solubilization.

According to Lebanon's first biennial update report to the UN Framework Convention on Climate Change (UNFCCC), consumption of chemical fertilizer in Lebanon increased progressively in recent years (MoE/UNDP/ GEF, 2015). The present study was therefore undertaken to isolate $\mathrm{P}$-solubilizing bacteria from the rhizosphere of some plants cultivated in various areas in El-Bekaa, Lebanon, evaluate their P-solubilization efficiency and identify the most potent P-solubilizing isolates. As well as, studying the effect of selected isolates, having high P-solubilizing potential, on the growth parameters and plant nutrition of some cultivated plants.

\section{Materials and Methods}

Samples

Thirty soil samples used for the isolation of the phosphate solubilizing bacteria (PSB) were collected from different rhizospheric soil samples at $30 \mathrm{~cm}$ depth from various areas in Chtaura, El-Bekaa, Lebanon (33 49' 0" North, $35^{\circ} 51^{\prime}$ '0" East).

Isolation, cultivation and selection of phosphate solubilizing bacteria

Phosphate-solubilizing bacteria were isolated from collected rhizospheric soil samples. One gm of each soil sample was suspended in $9 \mathrm{~mL}$ sterile distilled water. One hundred $\mu$ of each serially diluted (up to $10^{-5}$ ) suspension were plated on Pikovskaya medium (PVK) and National Botanical Research Institute's phosphate growth medium (NBRIP) supplemented with $\mathrm{Ca}_{3}\left(\mathrm{PO}_{4}\right)_{2}$ (TCP) as the sole P source. NBRIP composition was $(\mathrm{gm} / \mathrm{L})$ : D-glucose, $10 ; \mathrm{Ca}_{3}\left(\mathrm{PO}_{4}\right)_{2}, 5$; $\mathrm{MgCl}_{2} \cdot{ }^{\top} \mathrm{H}_{2} \mathrm{O}, 5 ; \mathrm{MgSO}_{4} \cdot \vee \mathrm{H}_{2} \mathrm{O}, 0.25 ; \mathrm{KCl}$, 0.2 ; $\left(\mathrm{NH}_{4}\right)_{2} \mathrm{SO}_{4}, 0.1$; agar, 15 ; final $\mathrm{pH}: 7 \pm 0.2$. PVK composition was (gm/L): D-glucose, 10; $\mathrm{Ca}_{3}\left(\mathrm{PO}_{4}\right)_{2}, 5 ;\left(\mathrm{NH}_{4}\right)_{2} \mathrm{SO}_{4}, 0.5 ; \mathrm{NaCl}, 0.2$; $\mathrm{MgSO}_{4} \cdot \mathrm{V}_{2} \mathrm{O}, 0.1 ; \mathrm{KCl}, 0.2$; yeast extract, 0.5 ; $\mathrm{MnSO}_{4} \cdot \mathrm{H}_{2} \mathrm{O}, 0.002 ; \mathrm{FeSO}_{4} \cdot{ }^{\vee} \mathrm{H}_{2} \mathrm{O}, 0.002 ;$ agar, 15; final pH: $7 \pm 0.2$. Plates were incubated for 7 days at $30^{\circ} \mathrm{C}$. Colonies showed clear zone around them were purified and preserved on slants containing the same medium of isolation (Mujahid et al., 2015; Li et al., 2019). Isolates were Gram stained.

Thirteen selected isolates were tested to compare their phosphate-solubilizing ability and detect the most potent strain. To prepare a seed culture, transfers from a bacterial slant $(24 \mathrm{hrs}$ old) were inoculated into $250 \mathrm{~mL}$ Erlenmeyer flasks containing $50 \mathrm{ml}$ PVK or NBRIP. The culture was grown aerobically by shaking (170rpm) at $30^{\circ} \mathrm{C}$ for $18 \mathrm{hrs}$ until reached an absorbance equivalent to $1\left(\mathrm{~A}_{600 \mathrm{~nm}}=1\right)$.

\section{Qualitative estimation of phosphate solubilization}

Phosphate solubilizing activity of each isolate was assayed qualitatively by spotting $10 \mu \mathrm{L}$ of each seed culture on the top of NBRIP and PVK media plates. The plates were incubated at $30^{\circ} \mathrm{C}$ for one week, then the clear halo around the colony was measured. Phosphate solubilization efficiency (PSE) and phosphate solubilization 
index (PSI) were determined (Nguyen et al., 1992; Edi-Premono et al., 1996).

Solubilization efficiency $(\mathrm{SE})=($ Solubilization diameter - Colony diameter $) /($ Colony diameter $) \times$ 100

Solubilization index $(\mathrm{SI})=($ Solubilization diameter + Colony diameter $) /($ Colony diameter $)$

\section{Quantitative determination of phosphate solubilization}

Inocula $(2 \%)$ from seed cultures of selected isolates were introduced to $50 \mathrm{~mL}$ of liquid PVK or NBRIP dispensed in $250 \mathrm{~mL}$ Erlenmeyer flasks then incubated at $30^{\circ} \mathrm{C}$ under shaken condition (170rpm) for 8 days. After incubation, cells were removed by centrifugation and the supernatant was used to determine the amount of soluble phosphorus. This was done by the molybdenumblue method (Murphy \& Riley, 1962). One ml of the supernatant was mixed with $200 \mu \mathrm{L}$ of the reagent (Ammonium molybdate (4\%), ascorbic acid $(0.1 \mathrm{M})$, sulfuric acid $(5 \mathrm{~N})$, and $50 \mu \mathrm{L}$ distilled water, heated in a water bath at $60^{\circ} \mathrm{C}$ for $30 \mathrm{~min}$, after cooling the formed blue colour was measured at $827 \mathrm{~nm}$ against a blank prepared in the same manner using distilled water. A calibration curve was prepared using standard solution of potassium dihydrogen phosphate. The percentage of phosphate solubilization was calculated according to the following formula (Nandish, 2005):

Phosphate solubilisation $\quad(\%)=\quad$ (Initial phosphate concentration - Residual phosphate concentration)/(Initial phosphate concentration) $\times 100$

\section{Identification of the most potent isolate}

The identification of the most potent isolates was carried using API 20 E (Biomerieux) and gene encodes 16S rRNA sequence analysis. From a single colony, the total genomic DNA was extracted and purified, then 16S rDNA was amplified using $8 \mathrm{~F}$ as forward primer (AGA GTT TGA TCC TGG CTC AG) and U1492R as reverse primer (GGT TAC CTT GTT ACG ACT T) (Shaheen et al., 2016). The PCR product was purified and sequenced. The PCR product was purified using Gene JETTM PCR Purification Kit (Thermo K0701). The purified product was sequenced in GATC Biotech (Germany) using ABI 3730xl DNA sequencer. The sequences obtained were aligned with known 16S rDNA sequences in the Genbank database using NCBI BLAST (Basic local alignment search tool) to generate the percent homology with recorded identified strains. Nucleotide sequences were submitted to GenBank under the accession numbers obtained for each isolate.

Factors affecting phosphate solubilisation by the most potent isolates (PSB8 and PSB13)

Effect of incubation period and inoculum size

The most potent isolates (PSB8 and PSB13) were grown on liquid NBRIP and cultivated under shaken conditions (170rpm) at $30^{\circ} \mathrm{C}$ for 8 days. Quantitative determination of phosphate solubilisation and bacterial biomass assay were monitored at different incubation period (1-14 days) and when using various inoculum size $(1-6 \%, v / v)$. The dry weight was determined by harvesting cells from cultures by centrifugation, cells were washed with $0.1 \mathrm{~N} \mathrm{HCl}$ to solubilize the remaining TCP, then washed with distilled water and re-centrifuged. The cell pellets were dried at $60^{\circ} \mathrm{C}$ until a constant weight was achieved using an analytical balance.

\section{Plackett-Burman design}

The Plackett-Burman experimental design, a fractional factorial design, was applied to reflect the relative importance of various factors on phosphate solubilization in liquid cultures. Total number of trials to be carried out according to Plackett-Burman was $\mathrm{K}+1$, where $\mathrm{k}$ was a number of independent variables (medium components and culture conditions). Each variable was represented at two levels, high and low, which were denoted by $(+)$ and $(-)$, respectively (Table 1$)$. The number of positive signs and negative signs per trial were $(\mathrm{k}+1) / 2$ and $(\mathrm{k}-1) / 2$, respectively. Each column contained equal number of positive and negative signs. The main effect of each variable was determined using the following equation:

$\mathrm{Exi}=\left(\sum \mathrm{Mi}+-\sum \mathrm{Mi}-\right) / \mathrm{N}$

where Exi is the variable main effect, $\mathrm{Mi}+$ and $\mathrm{Mi}-$ are the percentages of phosphate solubilization in trials where the independent variable (xi) was present in high or low level, respectively, and $\mathrm{N}$ is the number of trials divided by two (Plackett \& Burman, 1946). Using Microsoft Excel, statistical t-values for equal unpaired samples were calculated for determination of variable significance. 
TABLE 1. Variables and their levels employed in Plackett-Burman design for screening of some factors affecting phosphate solubilization by Pseudomonas sp

\begin{tabular}{lcccc}
\hline Symbol & Variable & Low (-) & Basal (0) & High (+) \\
\hline $\mathrm{A}$ & Glucose & 5 & 10 & 15 \\
$\mathrm{~B}$ & $\mathrm{Ca}_{3}\left(\mathrm{PO}_{4}\right)_{2}$ & 3 & 5 & 7 \\
$\mathrm{C}$ & $\mathrm{MgCl}_{2} \cdot 6 \mathrm{H}_{2} \mathrm{O}$ & 3 & 5 & 7 \\
$\mathrm{D}$ & $\mathrm{MgSO}_{4} \cdot 7 \mathrm{H}_{2} \mathrm{O}$ & 0.15 & 0.25 & 0.35 \\
$\mathrm{E}$ & $\mathrm{KCl}_{\mathrm{FCl}}$ & 0.1 & 0.2 & 0.3 \\
$\mathrm{~F}$ & $\left(\mathrm{NH}_{4}\right)_{2} \mathrm{SO}_{4}$ & 0.05 & 0.1 & 0.15 \\
$\mathrm{G}$ & Volume $(\mathrm{ml})$ & 30 & 50 & 70 \\
\hline
\end{tabular}

HD and Escherichia sp. HD grown on NBRIP

Application of PSB8 and PSB13 as biofertilizers on plants

In vitro cultivation of different plants was applied to reflect the relative importance of most potent isolates (PSB8 and PSB13) as biofertilizers on growth parameter of melon (Cucumis melo var. inodorus), horse-bean (Vicia faba), cucumber (Cucumis sativus), Armenian cucumber (Cucumis melo var. flexuosus), bean (Phaseolus vulgaris) and squash (Cucurbita pepo). Seeds were surfacesterilized with ethanol $95 \%$ for $1 \mathrm{~min}$, followed by $1 \%$ sodium hypochlorite for $30 \mathrm{~min}$, washed extensively with sterile water (Collavino et al., 2010). Seeds were grown in $500 \mathrm{~mL}$ plastic pots with sterile or fresh soil. The seeds were soaked with bacterial cells at a density of about $10^{8}$ colonies forming units (CFU) per milliliter. The experiment was performed under controlled environmental conditions $\left(25 \pm 1 / 20 \pm 2^{\circ} \mathrm{C}\right.$ day/ night temperature) and watered regularly. Treatments were designed in sterile and fresh soil as described in Table 2

TABLE 2. Different treatments applied as biofertilizers on studied plants

\begin{tabular}{lc}
\hline Symbol & Treatment \\
\hline 1 & Water \\
2 & water and TCP \\
3 & water and TCP with PSB8 \\
4 & water and TCP with PSB13 \\
5 & water and TCP with PSB13 and PSB8 \\
6 & water with nitrogen, phosphorous and \\
7 & potassium (NPK) fertilizer \\
8 & water and NPK with PSB8 \\
9 & water and NPK with PSB13 \\
\hline
\end{tabular}

After 40 days, the plants were harvested. The roots and the shoots were removed and their lengths and dry weights were determined.

\section{$\underline{\text { Results }}$}

Isolation and selection of the most potent phosphate solubilizing bacteria

Thirteen selected phosphate solubilizing isolates were rod-shaped Gram-negative bacteria; their colonies had smooth surface and creamy color. Data represented in Table 3 showed that the maximum phosphate solubilization index (PSI) (3.62) and the maximum phosphate solubilization efficiency (PSE) (162.85) on PVK, as well as the maximum PSI (7.00) and the maximum PSE (500.00) determined on NBRIP, were exhibited by PSB13. The efficiency of PSB13 was followed by that of PSB8 which showed high phosphate solubilization efficiency represented by PSI (3.00) and PSE (100.00) on PVK as well as PSI (5.66) and PSE (366.66) on NBRIP. Therefore, PSB13 and PSB8 were selected for further experiments.

\section{Identification of PSB8 and PSB 13 isolated strains}

PSB8 was identified using API $20 \mathrm{NE}$ as Pseudomonas fluorescence with $99.1 \%$ similarity. PSB13 was identified using API20 Eas Escherichia vulneris with $84.2 \%$ similarity. Whereas, the $16 \mathrm{~S}$ rRNA sequences of PSB8 and PSB13 showed 91 and $96 \%$ similarity with Pseudomonas fluorescens F113 (NC 016830.1) and Escherichia vulneris NBRC 102420 (GCF_000759795.1) recorded in the databases, respectively. Based on these biochemical and phylogenetic characterization results, the experimental bacterial isolates PSB8 and PSB13 were identified, res9-+pectively, as members of the genera Pseudomonas and Escherichia; thus, they were named Pseudomonas sp. HD (MW390992) and Escherichia sp. HD (MW392535), respectively. 
TABLE 3. Phosphate solubilization index (PSI) and phosphate solubilization efficiency (PSE) of the bacterial isolates grown on PVK and NBRI

\begin{tabular}{|c|c|c|c|c|c|}
\hline Medium & PSB & $\begin{array}{l}\text { Solubilization zone } \\
\text { diameter }(\mathrm{mm})[\mathrm{Z}]\end{array}$ & $\begin{array}{l}\text { Bacterial } \\
\text { colony } \\
\text { diameter } \\
(\mathbf{m m})[\mathrm{C}]\end{array}$ & $\begin{array}{l}\text { Phosphate solubilization } \\
\text { index } \\
\qquad \begin{array}{l}(\mathrm{PSI})=(\mathrm{Z}+\mathrm{C}) / \mathrm{C}\end{array}\end{array}$ & $\begin{array}{l}\text { Phosphate solubilization } \\
\text { efficiency } \\
(\mathrm{PSE})=(\mathrm{Z}-\mathrm{C}) / \mathrm{C} \times 100\end{array}$ \\
\hline \multirow{13}{*}{$\stackrel{1}{2}$} & 1 & 10.50 & 8.20 & 2.28 & 28.04 \\
\hline & 2 & 11.00 & 8.50 & 2.29 & 29.41 \\
\hline & 3 & 11.20 & 9.00 & 2.24 & 24.44 \\
\hline & 4 & 10.60 & 8.10 & 2.30 & 30.86 \\
\hline & 5 & 10.50 & 7.50 & 2.40 & 40.00 \\
\hline & 6 & 10.20 & 7.10 & 2.43 & 43.66 \\
\hline & 7 & 12.00 & 8.10 & 2.48 & 48.14 \\
\hline & 8 & 8.20 & 4.10 & 3.00 & 100.00 \\
\hline & 9 & 11.00 & 9.00 & 2.22 & 22.22 \\
\hline & 10 & 9.20 & 7.50 & 2.22 & 22.66 \\
\hline & 11 & 10.10 & 6.10 & 2.65 & 65.57 \\
\hline & 12 & 10.20 & 9.20 & 2.10 & 10.86 \\
\hline & 13 & 9.20 & 3.50 & 3.62 & 162.85 \\
\hline \multirow{13}{*}{$\frac{\hat{z}}{\hat{n}}$} & 1 & 9.20 & 6.00 & 2.53 & 53.33 \\
\hline & 2 & 8.50 & 5.20 & 2.63 & 63.46 \\
\hline & 3 & 10.00 & 6.00 & 2.66 & 66.66 \\
\hline & 4 & 6.20 & 2.00 & 4.10 & 210.00 \\
\hline & 5 & 7.50 & 2.00 & 4.75 & 275.00 \\
\hline & 6 & 11.00 & 6.90 & 2.59 & 59.42 \\
\hline & 7 & 6.00 & 1.50 & 5.00 & 300.00 \\
\hline & 8 & 7.00 & 1.50 & 5.66 & 366.66 \\
\hline & 9 & 9.00 & 5.50 & 2.63 & 63.63 \\
\hline & 10 & 9.00 & 5.00 & 2.80 & 80.00 \\
\hline & 11 & 8.10 & 2.00 & 5.05 & 305.00 \\
\hline & 12 & 9.10 & 6.00 & 2.51 & 51.66 \\
\hline & 13 & 6.00 & 1.00 & 7.00 & 500.00 \\
\hline
\end{tabular}

Incubation time and inoculum size affecting phosphate solubilization by Pseudomonas sp. HD and Escherichia sp. HD

The findings displayed in Fig. 1 revealed that the highest percentage of phosphate solubilization (73.60 and $87.81 \%$ ) and the highest biomass (24.05 and $30.05 \mathrm{mg} / \mathrm{mL}$ ) recorded for Pseudomonas sp. HD and Escherichia sp. HD, respectively, were obtained after incubation for 8 days. Shorter and longer time intervals exhibited least results. The best inoculum size that led to maximum phosphate solubilization by Pseudomonas sp. HD and Escherichia sp. HD was 4\% v/v (76.60 and $88.21 \%$, respectively) (Fig. 2). These conditions were set for further experiment.

Investigation of factors influencing phosphate solubilisation by Pseudomonas sp. HD and Escherichia sp. HD using multi-factorial statistical design: Plackett-Burman design

Phosphate solubilization percentage showed a wide variation throughout trials of the experiment. Trial 2 (Table 4) was found to have the highest influence on phosphate solubilisation. The modified culture medium of Trial 2 contained $(\mathrm{gm} / \mathrm{L})$ : glucose, $15 ; \mathrm{Ca}_{3}\left(\mathrm{PO}_{4}\right)_{2}, 7 ; \mathrm{MgCl}_{2} \cdot 6 \mathrm{H}_{2} \mathrm{O}$, 3; $\mathrm{MgSO}_{4} \cdot 7 \mathrm{H}_{2} \mathrm{O}, 0.35 ; \mathrm{KCl}, 0.1 ;\left(\mathrm{NH}_{4}\right)_{2} \mathrm{SO}_{4}$, 0.05 , the volume of culture medium was $70 \mathrm{~mL} /$ 
$250 \mathrm{~mL}$ flask inoculated with $4 \% \mathrm{v} / \mathrm{v}$ inoculum and incubated for 8 days at $30^{\circ} \mathrm{C}$ under shaken condition at $170 \mathrm{rpm}$. Conditions of Trial 2 showed phosphate solubilization percentages of 79.08 and 93.77\%, respectively for Pseudomonas sp. HD and Escherichia sp. HD which were greater than that recorded using the basal medium (76.60 and $88.21 \%$, respectively for Pseudomonas sp. HD and Escherichia sp. HD).

The main effect (that was examined as a difference between both averages of measurements made at high level $(+1)$ and the low level (-1) of the factor) of each examined factor affecting phosphate solubilization, was calculated for Pseudomonas sp. HD (Table 5) and for Escherichia sp. HD (Table 6). The analysis of the regression coefficients of the eight factors clarified that $\mathrm{MgCl}_{2} \cdot 6 \mathrm{H}_{2} \mathrm{O}, \mathrm{KCl},\left(\mathrm{NH}_{4}\right)_{2} \mathrm{SO}_{4}$ and culture volume showed a negative effect, whereas the other factors (glucose, $\mathrm{Ca}_{3}\left(\mathrm{PO}_{4}\right)_{2}$ and $\mathrm{MgSO}_{4} .7 \mathrm{H}_{2} \mathrm{O}$ ) resulted in a positive effect for Pseudomonas sp. HD and Escherichia sp. HD. Statistical analysis of the data is demonstrated for Pseudomonas sp. HD in Table 4 and for Escherichia sp. HD in Table 5 as t-value for the seven experimental variables. The significance level was determined using the student's t-test. The t-test for any individual effect allows an evaluation of the propability of finding the observed effect purely by chance. The factor which showed a high confidence percentage was glucose, where it was the most positive significant variable affecting phosphate solubilization by Pseudomonas sp. HD and Escherichia sp. HD.
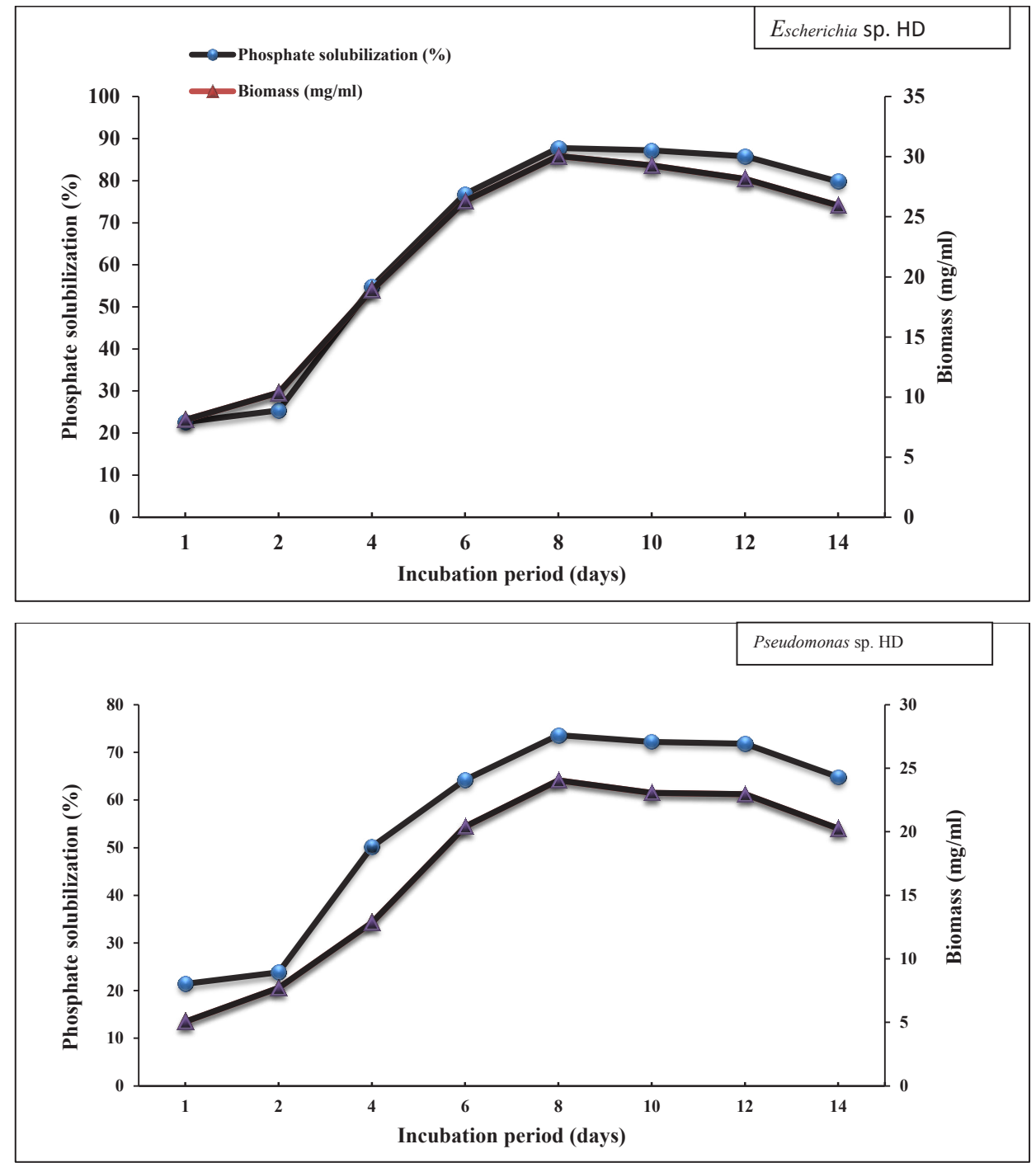

Fig. 1. Effect of incubation period on biomass and phosphate solubilization by Escherichia sp. HD and Pseudomonas sp. HD grown on NBRIP 

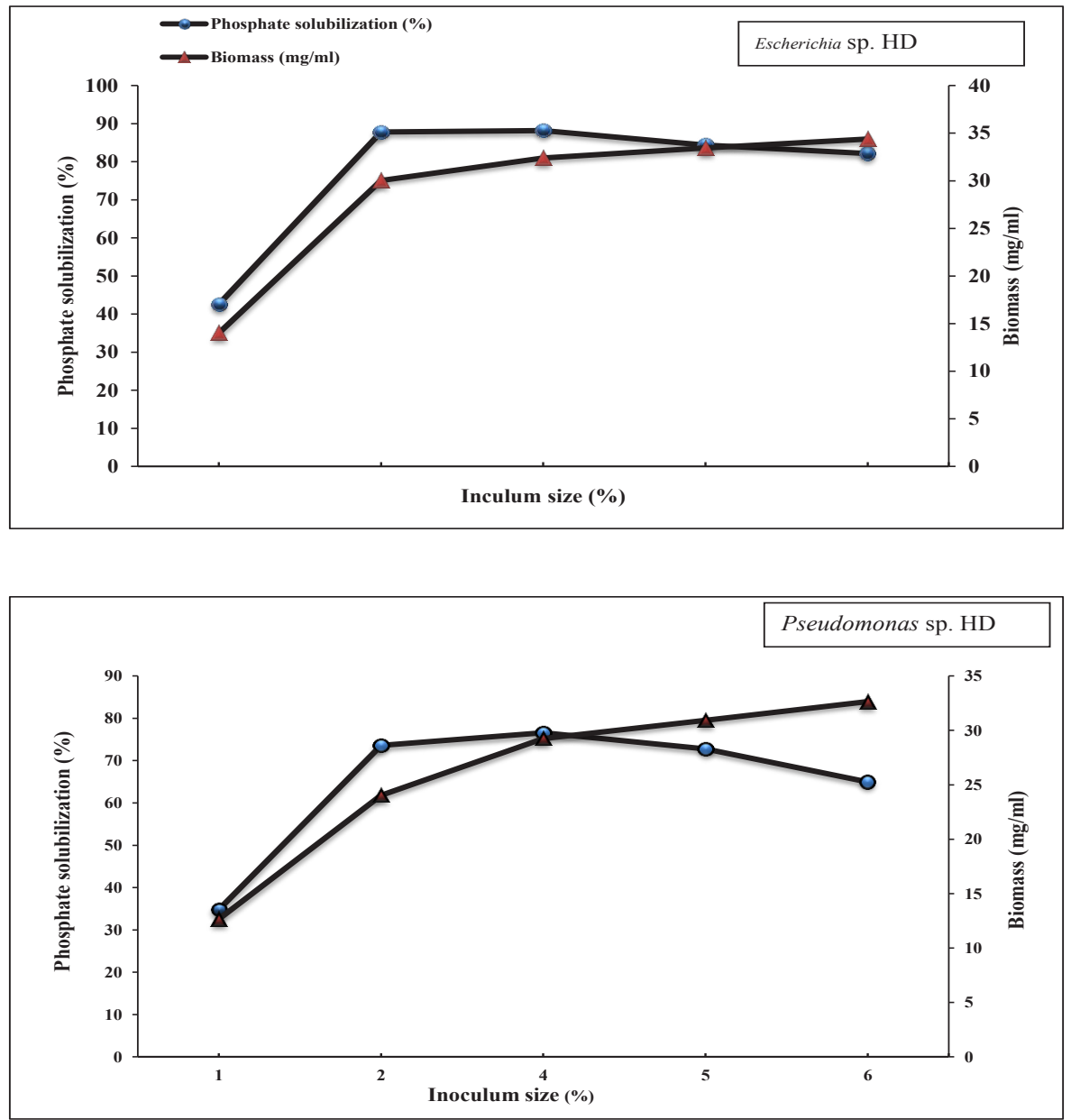

Fig. 2. Effect of inoculum size on biomass and phosphate solubilization by Escherichia sp. HD and Pseudomonas sp. HD and grown on NBRIP

Application of Pseudomonas sp. HD and Escherichia sp. HD as biofertilizers on plants

The obtained results of the application of Pseudomonas sp. HD and Escherichia sp. HD as biofertilizers on growth parameters of the studied plants are presented in Table 7. Generally, shoot length, root length, shoot dry weight and root dry weight for melon gave approximately the same results in fresh and sterile soil. In addition, the use of TCP with bacterial inoculants in all treatments gave more promising results than the use of a direct chemical fertilizer NPK. Moreover, the plant growth reached its maximum in treatment 5 (water and TCP with Pseudomonas sp. HD and Escherichia sp in seed) and its minimum in treatment 1 (water). Same results were observed for other plants.

\section{Discussion}

Most of the microorganisms used as biological fertilizers are isolated from the plant rhizosphere (Soumare et al., 2020). In the current study, phosphate solubilizing bacteria were isolated from the rhizosphere soil collected from various areas in El-Bekaa-Lebanon. Screening experiments were performed with thirteen phosphate solubilizing bacterial isolates to explore their potential to solubilize the insoluble tricalcium phosphate supplemented to NBRIP and PVK as the sole $\mathrm{P}$ source. The maximum phosphate solubilization efficiency, assessed by PSI and PSE, was exhibited by Escherichia sp. HD followed by Pseudomonas sp. HD. Kalayu (2019) reported the diverse organic acids released by Gram negative bacteria, which render Gram negative bacteria more effective in dissolving mineral phosphates than Gram-positive bacteria. He mentioned that Pseudomonas is among the most efficient $\mathrm{P}$ solubilizers. 
TABLE 4. Randomized Plackett-Burman experimental design for evaluating factors influencing phosphate solubilization by Pseudomonas sp. HD and Escherichia sp. HD grown on NBRIP

\begin{tabular}{|c|c|c|c|c|c|c|c|c|c|c|c|}
\hline Trial & A & B & C & D & $\mathbf{E}$ & $\mathbf{F}$ & $\mathbf{G}$ & $\begin{array}{c}\text { P solubilization } \\
\% \text { by } \\
\text { Pseudomonas } \\
\text { sp. } \\
\text { HD } \\
\end{array}$ & $\begin{array}{c}\text { P Solubilization } \\
\text { \% by } \\
\text { Escherichia sp. } \\
\text { HD }\end{array}$ & $\begin{array}{c}\text { Biomass } \\
\text { (mg/mL) by } \\
\text { Pseudomonas } \\
\text { sp. } \\
\text { HD }\end{array}$ & $\begin{array}{c}\text { Biomass } \\
(\mathrm{mg} / \mathrm{mL}) \text { by } \\
\text { Escherichia } \\
\text { sp. } \\
\text { HD }\end{array}$ \\
\hline 1 & + & + & + & - & + & - & - & 70.34 & 80.21 & 24.65 & 30.05 \\
\hline 2 & + & + & - & + & - & - & + & 79.08 & 93.77 & 26.45 & 33.10 \\
\hline 3 & + & - & + & - & - & + & + & 69.34 & 75.01 & 24.10 & 29.60 \\
\hline 4 & - & + & - & - & + & + & + & 64.10 & 72.31 & 21.20 & 25.25 \\
\hline 5 & + & - & - & + & + & + & - & 75.32 & 87.25 & 25.05 & 32.15 \\
\hline 6 & - & - & + & + & + & - & + & 60.20 & 70.50 & 20.15 & 24.70 \\
\hline 7 & - & + & + & + & - & + & - & 62.40 & 70.20 & 20.05 & 24.10 \\
\hline 8 & - & - & - & - & - & - & - & 70.25 & 80.40 & 22.60 & 30.25 \\
\hline 9 & 0 & 0 & 0 & 0 & 0 & 0 & 0 & 76.60 & 88.21 & 25.26 & 32.40 \\
\hline
\end{tabular}

TABLE 5. Degree of positive and negative effects of independent variables on phosphate solubilization (\%) by Pseudomonas sp. HD grown on NBRIP according to levels in the Plackett-Burman experiment

\begin{tabular}{|c|c|c|c|c|c|c|c|c|c|}
\hline \multirow{3}{*}{$\begin{array}{l}\text { Variable } \\
\text { A }\end{array}$} & \multicolumn{5}{|c|}{ Phosphate solubilization (\%) } & \multirow{3}{*}{$\begin{array}{l}\text { Mean } \\
73.52 \\
64.23\end{array}$} & \multirow{3}{*}{$\begin{array}{l}\begin{array}{c}\text { Main } \\
\text { effect }\end{array} \\
9.2825\end{array}$} & \multirow{3}{*}{$\begin{array}{c}\text { T-value } \\
2.965372\end{array}$} & \multirow{3}{*}{$\begin{array}{c}\begin{array}{c}\text { Degree of } \\
\text { significance } \\
(\%)\end{array} \\
95\end{array}$} \\
\hline & + & 70.34 & 79.08 & 69.34 & 75.32 & & & & \\
\hline & - & 64.10 & 60.20 & 62.40 & 70.25 & & & & \\
\hline \multirow{2}{*}{ B } & + & 70.34 & 79.08 & 64.10 & 62.40 & 68.98 & \multirow{2}{*}{0.2025} & \multirow[t]{2}{*}{0.041204} & \multirow{2}{*}{95} \\
\hline & - & 69.34 & 75.32 & 60.20 & 70.25 & 68.77 & & & \\
\hline \multirow{2}{*}{$\mathrm{C}$} & + & 70.34 & 69.34 & 60.20 & 62.40 & 65.57 & \multirow{2}{*}{-6.6175} & \multirow[t]{2}{*}{-1.61158} & \multirow{2}{*}{95} \\
\hline & - & 79.08 & 64.10 & 75.32 & 70.25 & 72.18 & & & \\
\hline \multirow{2}{*}{$\mathrm{D}$} & + & 79.08 & 75.32 & 60.20 & 62.40 & 69.25 & \multirow{2}{*}{0.7425} & \multirow[t]{2}{*}{0.151349} & \multirow{2}{*}{95} \\
\hline & - & 70.34 & 69.34 & 64.10 & 70.25 & 68.50 & & & \\
\hline \multirow{2}{*}{$\mathrm{E}$} & + & 70.34 & 64.10 & 75.32 & 60.20 & 67.49 & \multirow{2}{*}{-2.7775} & \multirow[t]{2}{*}{-0.58074} & \multirow{2}{*}{95} \\
\hline & - & 79.08 & 69.34 & 62.40 & 70.25 & 70.26 & & & \\
\hline \multirow{2}{*}{$\mathrm{F}$} & + & 69.34 & 64.10 & 75.32 & 62.40 & 67.79 & \multirow{2}{*}{-2.1775} & \multirow[t]{2}{*}{-0.45044} & \multirow{2}{*}{95} \\
\hline & - & 70.34 & 79.08 & 60.20 & 70.25 & 69.96 & & & \\
\hline \multirow{2}{*}{ G } & + & 79.08 & 69.34 & 64.10 & 60.20 & 68.18 & \multirow{2}{*}{-1.3975} & \multirow[t]{2}{*}{-0.28625} & \multirow{2}{*}{95} \\
\hline & - & 70.34 & 75.32 & 62.40 & 70.25 & 69.57 & & & \\
\hline
\end{tabular}


TABLE 6. Degree of positive and negative effects of independent variables on phosphate solubilization (\%) by Escherichia sp. HD grown on NBRIP according to levels in the Plackett-Burman experiment

\begin{tabular}{|c|c|c|c|c|c|c|c|c|c|}
\hline \multirow{3}{*}{$\begin{array}{l}\text { Variable } \\
\text { A }\end{array}$} & \multicolumn{5}{|c|}{ Phosphate solubilization (\%) } & \multirow{2}{*}{$\begin{array}{l}\text { Mean } \\
84.06\end{array}$} & \multirow{3}{*}{ 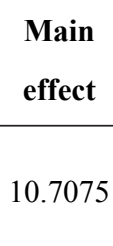 } & \multirow{3}{*}{$\begin{array}{l}\text { T-value } \\
2.25728\end{array}$} & \multirow{3}{*}{$\begin{array}{c}\begin{array}{c}\text { Degree of } \\
\text { significance } \\
(\%)\end{array} \\
95\end{array}$} \\
\hline & + & 80.21 & 93.77 & 75.01 & 87.25 & & & & \\
\hline & - & 72.31 & 70.50 & 70.20 & 80.40 & 93.45 & & & \\
\hline \multirow{2}{*}{ B } & + & 80.21 & 93.77 & 72.31 & 70.20 & 79.12 & \multirow{2}{*}{0.8325} & \multirow[t]{2}{*}{0.129238} & \multirow{2}{*}{95} \\
\hline & - & 75.01 & 87.25 & 70.50 & 80.40 & 78.29 & & & \\
\hline \multirow{2}{*}{$\mathrm{C}$} & + & 80.21 & 75.01 & 70.50 & 70.20 & 73.98 & \multirow{2}{*}{-9.4525} & \multirow[t]{2}{*}{-1.82871} & \multirow{2}{*}{95} \\
\hline & - & 93.77 & 72.31 & 87.25 & 80.40 & 83.43 & & & \\
\hline \multirow{2}{*}{$\mathrm{D}$} & + & 93.77 & 87.25 & 70.50 & 70.20 & 80.43 & \multirow{2}{*}{3.4475} & \multirow[t]{2}{*}{0.547645} & \multirow{2}{*}{95} \\
\hline & - & 80.21 & 75.01 & 72.31 & 80.40 & 76.98 & & & \\
\hline \multirow{2}{*}{$\mathrm{E}$} & + & 80.21 & 72.31 & 87.25 & 70.50 & 77.56 & \multirow{2}{*}{-2.2775} & \multirow[t]{2}{*}{-0.3568} & \multirow{2}{*}{95} \\
\hline & - & 93.77 & 75.01 & 70.20 & 80.40 & 79.84 & & & \\
\hline \multirow[b]{2}{*}{$\mathrm{F}$} & + & 75.01 & 72.31 & 87.25 & 70.20 & 76.19 & \multirow{2}{*}{-5.0275} & \multirow[t]{2}{*}{-0.82212} & \multirow{2}{*}{95} \\
\hline & - & 80.21 & 93.77 & 70.50 & 80.40 & 81.22 & & & \\
\hline \multirow{2}{*}{ G } & + & 93.77 & 75.01 & 72.31 & 70.50 & 77.89 & \multirow{2}{*}{-1.6175} & \multirow[t]{2}{*}{-0.25208} & \multirow[b]{2}{*}{95} \\
\hline & - & 80.21 & 87.25 & 70.20 & 80.40 & 79.51 & & & \\
\hline
\end{tabular}

Phosphate solubilizing microorganisms are able to use phosphate in their metabolic processes, they differ in their requirements for maximal activity. In the present study, Pseudomonas sp. HD and Escherichia sp. HD cultivated NBRIP medium showed the highest percentage of phosphate solubilization under shaken condition $(170 \mathrm{rpm})$ at $30^{\circ} \mathrm{C}$. The percentage of phosphate solubilization was influenced by the incubation period; during the first days of incubation, phosphate solubilization percentage increased, to reach the maxiumum level at day 8 (73.60 and $87.81 \%$ for Pseudomonas sp. HD and Escherichia sp. HD, respectively), then decreased at longer incubation period. Such variations in phosphate solubilization were reported by Goenadi et al. (2000) and Laxmi et al. (2015). Reduction in release of soluble phosphorus during later phase of the incubation might be due to the depletion of nutrients in the culture medium, in particular, carbon source needed for the production of organic acids (Chaiharn \& Lumyong, 2011). The increase of the inoculum size from 2 to $4 \%$ enhanced the phosphate solubilization by Pseudomonas sp. HD and Escherichia sp. HD (76.60 and
$88.21 \%$, respectively). This may be attributed to the increase of bacterial biomass. Kolekar et al. (2017) found a positive correlation between the microbial biomass and phosphate solubilization.

Plackett-Burman design, applied in the current investigation, showed a great efficiency of phosphate solubilization, since the results demonstrated that the percentage of solubilization was enhanced in Trial 2 comparing with basal, from 76.60 to $79.08 \%$ for Pseudomonas sp. HD and from 88.21 to $93.77 \%$ for Escherichia sp. HD. The main effect of each variable was calculated according to the data recorded for the percentage of phosphate solubilization. The analysis of the regression coefficients of the eight factors clarified that $\mathrm{MgCl}_{2} \cdot 6 \mathrm{H}_{2} \mathrm{O}, \mathrm{KCl},\left(\mathrm{NH}_{4}\right)_{2} \mathrm{SO}_{4}$ and culture volume gave a negative effect, whereas the other factors (glucose, $\mathrm{Ca}_{3}\left(\mathrm{PO}_{4}\right)_{2}$ and $\mathrm{MgSO}_{4} .7 \mathrm{H}_{2} \mathrm{O}$ ) gave a positive effect, for Pseudomonas sp. HD and Escherichia sp. HD. Also, Verma \& Ekka (2017) and Mujahid et al. (2015) have reported that glucose as carbon source and $\left(\mathrm{NH}_{4}\right)_{2} \mathrm{SO}_{4}$ as nitrogen source have the positive effect on phosphate solubilization by PSB. 
TABLE 7. Effect of phosphate solubilizing bacteria on growth parameters of the studied plants

\begin{tabular}{|c|c|c|c|c|c|c|c|c|}
\hline \multirow{3}{*}{$\begin{array}{l}\text { Treat- } \\
\text { mentsnt }\end{array}$} & \multicolumn{8}{|c|}{ Parameters } \\
\hline & \multicolumn{2}{|c|}{ Shoot length (cm) } & \multicolumn{2}{|c|}{ Root length (cm) } & \multicolumn{2}{|c|}{ Shoot dry weight (gm) } & \multicolumn{2}{|c|}{ Root dry weight (g) } \\
\hline & Fresh soil & Sterile soil & Fresh soil & Sterile soil & Fresh soil & Sterile soil & Fresh soil & Sterile soil \\
\hline \multicolumn{9}{|c|}{ Melon (Cucumis melo var. inodorus) } \\
\hline 1 & 26.30 & 26.10 & 1.90 & 1.80 & 1.50 & 1.60 & 0.30 & 0.40 \\
\hline 2 & 26.10 & 26.00 & 1.80 & 1.70 & 1.40 & 1.50 & 0.30 & 0.20 \\
\hline 3 & 27.90 & 28.10 & 2.40 & 2.50 & 2.10 & 2.60 & 0.90 & 1.10 \\
\hline 4 & 28.50 & 28.60 & 2.60 & 2.80 .4 & 2.30 & 2.80 & 1.10 & 1.20 \\
\hline 5 & 28.60 & 28.90 & 2.80 & 3.206 & 2.40 & 2.90 & 1.20 & 1.50 \\
\hline 6 & 27.20 & 27.50 & 2.00 & 1.90 & 1.70 & 1.60 & 0.50 & 0.60 \\
\hline 7 & 27.30 & 27.20 & 2.10 & 2.10 & 1.90 & 1.90 & 0.60 & 0.70 \\
\hline 8 & 27.20 & 27.30 & 2.30 & 2.20 & 2.00 & 2.10 & 0.80 & 0.80 \\
\hline 9 & 27.80 & 27.60 & 2.60 & 2.50 & 2.10 & 2.20 & 0.90 & 1.10 \\
\hline \multicolumn{9}{|c|}{ horse-bean (Vicia faba) } \\
\hline 1 & 27.50 & 27.00 & 3.10 & 3.00 & 1.50 & 1.60 & 0.50 & 0.60 \\
\hline 2 & 27.30 & 26.90 & 2.80 & 2.70 & 1.40 & 1.30 & 0.30 & 0.40 \\
\hline 3 & 28.90 & 28.90 & 3.70 & 3.90 & 2.20 & 2.20 & 1.00 & 1.10 \\
\hline 4 & 29.70 & 29.50 & 3.80 & 4.10 & 2.30 & 2.40 & 1.30 & 1.40 \\
\hline 5 & 29.90 & 29.90 & 4.00 & 4.50 & 2.50 & 2.70 & 1.60 & 1.70 \\
\hline 6 & 27.80 & 27.90 & 3.30 & 3.50 & 1.70 & 1.70 & 0.70 & 0.70 \\
\hline 7 & 28.30 & 28.40 & 3.60 & 3.60 & 1.90 & 1.90 & 0.80 & 0.80 \\
\hline 8 & 28.50 & 28.70 & 3.80 & 3.80 & 2.10 & 2.10 & 1.00 & 1.00 \\
\hline 9 & 28.80 & 28.90 & 3.90 & 3.90 & 2.20 & 2.20 & 1.20 & 1.20 \\
\hline \multicolumn{9}{|c|}{ Cucumber (Cucumis sativus) } \\
\hline 1 & 23.10 & 23.00 & 1.30 & 1.10 & 1.40 & 0.90 & 0.30 & 0.20 \\
\hline 2 & 22.80 & 22.70 & 1.20 & 1.00 & 1.20 & 0.80 & 0.20 & 0.10 \\
\hline 3 & 25.10 & 25.30 & 2.20 & 2.40 & 2.30 & 2.50 & 0.90 & 1.10 \\
\hline 4 & 25.30 & 25.70 & 2.40 & 2.60 & 2.50 & 2.60 & 1.20 & 1.40 \\
\hline 5 & 25.60 & 25.90 & 2.70 & 2.90 & 2.80 & 3.00 & 1.50 & 1.70 \\
\hline 6 & 23.70 & 23.80 & 1.60 & 1.70 & 1.60 & 1.20 & 0.50 & 0.60 \\
\hline 7 & 23.80 & 23.90 & 1.80 & 2.00 & 1.90 & 2.00 & 0.60 & 0.60 \\
\hline 8 & 23.90 & 24.10 & 2.00 & 2.10 & 2.10 & 2.20 & 0.70 & 0.80 \\
\hline 9 & 24.10 & 24.70 & 2.10 & 2.40 & 2.30 & 2.40 & 0.90 & 0.90 \\
\hline \multicolumn{9}{|c|}{ Armenian cucumber (Cucumis melo var. flexuosus) } \\
\hline 1 & 26.20 & 25.80 & 1.80 & 1.50 & 1.50 & 1.40 & 0.30 & 0.20 \\
\hline 2 & 26.00 & 25.70 & 1.60 & 1.50 & 1.30 & 1.30 & 0.20 & 0.10 \\
\hline 3 & 28.80 & 28.90 & 2.50 & 2.70 & 2.10 & 2.30 & 0.80 & 0.80 \\
\hline 4 & 29.50 & 29.90 & 2.70 & 2.90 & 2.30 & 2.50 & 1.00 & 1.10 \\
\hline 5 & 29.90 & 30.60 & 2.90 & 3.10 & 2.70 & 2.70 & 1.10 & 1.20 \\
\hline 6 & 27.00 & 26.80 & 2.00 & 1.90 & 1.60 & 1.60 & 0.50 & 0.50 \\
\hline 7 & 28.40 & 28.20 & 2.00 & 2.40 & 2.00 & 2.20 & 0.60 & 0.70 \\
\hline 8 & 28.90 & 28.60 & 2.40 & 2.60 & 2.20 & 2.40 & 0.80 & 0.80 \\
\hline 9 & 29.20 & 29.70 & 2.70 & 2.90 & 2.50 & 2.60 & 1.00 & 1.10 \\
\hline
\end{tabular}


TABLE 7. Cont.

\begin{tabular}{|c|c|c|c|c|c|c|c|c|}
\hline \multirow{3}{*}{$\begin{array}{l}\text { Treat- } \\
\text { mentsnt }\end{array}$} & \multicolumn{8}{|c|}{ Parameters } \\
\hline & \multicolumn{2}{|c|}{ Shoot length (cm) } & \multicolumn{2}{|c|}{ Root length (cm) } & \multicolumn{2}{|c|}{ Shoot dry weight (gm) } & \multicolumn{2}{|c|}{ Root dry weight (g) } \\
\hline & Fresh soil & Sterile soil & Fresh soil & Sterile soil & Fresh soil & Sterile soil & Fresh soil & Sterile soil \\
\hline \multicolumn{9}{|c|}{ Bean (Phaseolus vulgaris) } \\
\hline 1 & 67.40 & 67.70 & 5.50 & 5.20 & 2.30 & 2.20 & 0.60 & 0.50 \\
\hline 2 & 67.90 & 67.80 & 5.40 & 5.20 & 2.20 & 2.10 & $0.50 /$ & 0.50 \\
\hline 3 & 69.50 & 69.70 & 5.80 & 5.90 & 2.50 & 2.60 & 0.70 & 0.80 \\
\hline 4 & 69.70 & 70.50 & 5.90 & 6.10 & 2.70 & 2.80 & 0.90 & 0.90 \\
\hline 5 & 69.90 & 70.90 & 6.10 & 6.20 & 2.80 & 2.90 & 1.10 & 1.30 \\
\hline 6 & 68.50 & 68.90 & 5.60 & 5.70 & 2.40 & 2.50 & 0.60 & 0.70 \\
\hline 7 & 68.50 & 69.10 & 5.60 & 5.70 & 2.30 & 2.40 & 0.60 & 0.70 \\
\hline 8 & 68.80 & 69.50 & 5.80 & 5.90 & 2.50 & 2.70 & 0.80 & 0.80 \\
\hline 9 & 69.10 & 69.90 & 5.90 & 6.10 & 2.60 & 2.80 & 1.00 & 1.10 \\
\hline \multicolumn{9}{|c|}{ Squash (Cucurbita pepo) } \\
\hline 1 & 21.50 & 20.90 & 2.50 & 2.30 & 1.70 & 1.50 & 0.50 & 0.40 \\
\hline 2 & 20.10 & 20.30 & 2.10 & 2.00 & 1.80 & 1.30 & 0.40 & 0.30 \\
\hline 3 & 23.60 & 23.80 & 2.60 & 2.80 & 1.90 & 1.90 & 0.70 & 0.80 \\
\hline 4 & 23.60 & 23.80 & 2.20 & 2.50 & 1.70 & 1.60 & 0.60 & 0.70 \\
\hline 5 & 23.80 & 24.30 & 2.40 & 2.70 & 1.90 & 1.80 & 0.60 & 0.80 \\
\hline 6 & 23.40 & 24.10 & 2.10 & 2.40 & 1.70 & 1.70 & 0.30 & 0.80 \\
\hline 7 & 24.20 & 24.30 & 2.30 & 2.50 & 1.70 & 1.80 & 0.60 & 0.70 \\
\hline 8 & 24.60 & 25.10 & 2.50 & 2.70 & 1.80 & 1.90 & 0.70 & 0.70 \\
\hline 9 & 25.20 & 25.90 & 2.60 & 2.90 & 2.10 & 1.90 & 0.90 & 1.00 \\
\hline
\end{tabular}

(1) Water; (2) Water and TCP; (3) Water and TCP with Pseudomonas sp in seeds; (4) Water and TCP with Escherichia sp in seed; (5) Water and TCP with Pseudomonas sp. HD and Escherichia sp in seed; (6) Water with nitrogen, phosphorous and potassium (NPK) fertilizer; (7) Water and NPK with Pseudomonas sp in seed; (8) Water and NPK with Escherichia sp in seed and (9) Water and NPK with PSB8 and PSB13 in seed.

Development of biofertilizer technology was conducted to reduce the negative side effects of chemical fertilizer application (Aggani, 2013). Biofertilizers made of soil microorganisms gain importance for use in crop production because they are cheap, effective and environmental friendly. They have impact in restoring the soil's natural fertility and protecting it against drought, soil-borne diseases and therefore stimulate plant growth (Suhag, 2016). To minimize the dependence on phosphate fertilizers, inoculation of PSMs in soil or seed is known to enhance solubilization of applied and fixed phosphates in soil, resulting in better crop yield (Selvi et al., 2017). PSB (Pseudomonas sp. HD and Escherichia sp. HD) were in vivo testing as biofertilizers, they were used as microbial inoculants for six plants. Increased shoot length, root length, and shoot and root dry weight of the studied plants were recorded from the seedlings in treatment (5) where water and TCP with Pseudomonas sp. HD and
Escherichia sp. HD were inoculated in seeds. In accordance with this finding, Sarker et al. (2014) found that Pseudomonas sp. PSB8 significantly enhanced growth and nutrient uptake by wheat seedlings. Moreover, Omer (2016) reported that maize seeds inoculated with PSB resulted in an increase in biological yield reaching 55.2 and $33 \%$ over control for Pseudomonas geniculata and $P$. aeruginosa, respectively.

\section{Conclusion}

In the present study, the isolated bacterial strains Pseudomonas sp. HD and Escherichia sp. HD were able to solubilize phosphate (after optimization of the nutritional and environmental factors affecting phosphate solubilization process) with percentages 79.08 and 93.77 , respectively, within 8 days at $\mathrm{pH} 7,30^{\circ} \mathrm{C}$ and under shaken condition (170rpm). They are excellent candidates for phosphate solubilization in soil to become available to plants. Regarding environmental 
pollution due to excessive use of chemical fertilizers and high costs of $\mathrm{P}$ fertilizer production, these bacterial inoculants (Pseudomonas sp. HD and Escherichia sp. HD) tested may well be used as biofertilizers to enhance sustainable agricultural production.

Conflict of interests: The authors declare no conflict of interest.

Authors contribution: Dr. Salwa: Writing the article and following up its publication, in addition to participating in selecting the research point, planning the experiments and supervising their conduct. She carries out the experiment concerning the application of biofertilizers on plants. Dr. Hoda: Helping in the revision of the article and in revising the results of experiments. Hassan: Conducting the practical experiments of microbiology.

\section{Ethical approval: Not applicable.}

\section{References}

Aggani, S.L. (2013) Development of bio-fertilizers and its future perspective. Scholars Academic Journal of Pharmacy, 2, 327-332.

Ankit, K., Anil, P., Johri, B.N. (2011) Bacillus as PGPR in Crop Ecosystem. Bacteria in Agrobiology Crop Ecosystems, 2, 37-59.

Banik, S., Dey, B.K. (1982) Available phosphate content of an alluvial soil is influenced by inoculation of some isolated phosphate-solubilizing microorganisms. Plant Soil, 69, 353-364.

Caballero-Mellado, J., Onofre-Lemus, J., De los Santos E.P., Martinez-Aguilar, L. (2007) The tomato rhizosphere, an environment rich in nitrogen-fixing Burkholderia species with capabilities of interest for agriculture and bioremediation. Applied and Environmental Microbiology, 73, 5308-5319.

Chaiharn, M., Lumyong, S. (2011) Screening and optimization of indole-3-acetic acid production and phosphate solubilization from Rhizobacteria aimed at improving plant growth. Current Microbiology, 62, 173-181.

Collavino, M.M., Sansberro, P.A., Mroginski, L.A., Aguilar, O.M. (2010) Comparison of in vitro solubilization activity of diverse phosphate- solubilizing bacteria native to acid soil and their ability to promote Phaseolus vulgaris growth. Biology and Fertility of Soils, 46, 727-738.

Edi-Premono, M., Moawad, M.A., Vleck, P.L.G. (1996) Effect of phosphate solubilizing Pseudmonas putida on the growth of maize and its survival in the rhizosphere. Indonesian Journal of Crop Science, 11, 13-23.

Farhat, M.B., Farhat, M., Bejor, W., Kammoun, R. (2009) Characterization of the mineral phosphate solubilizing activity of Serratia marcescens CTM 50650 isolated from the phosphate mineral of Gafsan. Archives of Microbiology, 191, 815-824.

Goenadi, D., Siswanto, Sugiarto, Y. (2000) Bioactivation of poorly soluble phosphate rocks with a phosphorus solubilizing fungus. Soil Science Society of America Journal, 64, 927-932.

Goldstein, A.H. (1986) Bacterial mineral phosphate solubilization: historical perspectives and future prospects. American Journal of Alternative Agriculture, 1, 57-65.

Halder, A.K., Chakrabartty, P.K. (1993) Solubilization of inorganic phosphate by Rhizobium. Folia Microbiologica, 38, 325-330.

Halder, A.K., Mishra, A.K., Bhattacharyya, P., Chakrabartty, P.K. (1990) Solubilization of rock phosphate by Rhizobium and Bradyrhizobium. Journal of General and Applied Microbiology, 36, 81-92.

Hamdali, H., Bouizgarne, B., Hafidi, M., Lebrihi, A., Virolle, M.J., Ouhdouch, Y. (2008) Screening for rock phosphate solubilizing Actinomycetes from Moroccan phosphate mines. Applied Soil Ecology, 38, 12-19.

Kalayu, G. (2019) Phosphate solubilizing microorganisms: Promising approach as biofertilizers. International Journal of Agronomy, 7, 1-14.

Khan, M.S., Zaidi, A., Ahemad, M., Oves, M., Wani, P.A. (2010) Plant growth promotion by phosphate solubilizing fungi-current perspective. Archives of Agronomy and Soil Science, 56, 73-98.

Kolekar, S.S., Desal, P.D., Panchal, H.K., Shah, K.B. (2017) Study of phosphate solubilizing 
microorganisms with biofertilizer potential. International Journal of Pharma and Biology Sciences, 8, 751-757.

Laxmi, K.R., Merugu, R., Girisham S., Reddy, S.M. (2015) Phosphate solubilization by Allochromatium sp. Gskrlmbku-01 isolated from marine water of Visakhapatnam. International Journal of Applied Biology and Pharmaceutical Technology, 6, 1-6.

Li, Y., Zhang, J., Zhang, J., Xu, W., Mou, Z. (2019) Characteristics of inorganic phosphate-solubilizing bacteria from the sediments of a Eutrophic Lake. International Journal of Environmental Research and Public Health, 16, 2141-2155.

MoE/UNDP/GEF (2015) Lebanon's first biennial update report to the UNFCCC, Ministry of Environment, October, 2015, Beirut, Lebanon.

Mujahid, T.Y., Subhan, S.A., Wahab, A, Masnoon, J., Ahmed, N., Abbas, T. (2015) Effects of different physical and chemical parameters on phosphate solubilization activity of plant growth promoting bacteria isolated from indigenous soil. Journal of Pharmacy and Nutrition Sciences, 5, 64-70.

Murphy, J., Riley, J.P. (1962) A modified single solution method for the determination of phosphate in natural waters. Analytica Chimica Acta, 27, 31-36.

Nandish, M.S. (2005) Microbial degradation of phenol and pentachlorophenol. Thesis submitted for the degree of Master of Sciences in Agricultural Microbiology to the University of Agricultural Sciences, Dharwad, India. From http://www. ibrarian.net/navon/paper

Nguyen, C., Yan, W., Le Tacon, F., Lapeyrie, F. (1992) Genetic variability of phosphate solubilizing activity by monocaryotic \& dicaryotic mycelia of the ectomyccorhizal fungus Laccaria bicolor (Maire) P.D. Orton. Plant Soil, 143, 193-199.

Ohtake, H., Wu, H., Imazu, K., Ambe, Y., Kato, J., Kuroda, A. (1996) Bacterial phosphonate degradation, phosphite oxidation and polyphosphate accumulation. Resources Conservation and Recycling, 18, 125-134.

Omer, A. (2016) Role of endophytic Pseudomonas as plant growth promoters under desert conditions. Egyptian Journal of Desert Research, 66, 305-326.
Plackett, RL., Burman, J.P. (1946) The design of optimum multifactorial experiments. Biometrica, 33, 305-325.

Rengel, Z., Marschner, P. (2005) Nutrient availability and management in the rhizosphere: Exploiting genotypic differences. New Phytology, 168, 305312.

Rodriguez, H., Fraga, R. (1999) Phosphate solubilizing bacteria and their role in plant growth promotion. Biotechnology Advances, 17, 319-339.

Rossolini, G.M., Shippa, S., Riccio, M.L., Berlutti, F., Macaskie, L.E., Thaller, M.C. (1998) Bacterial nonspecific acid phosphatases: Physiology, evolution, and use as tools in microbial biotechnology. Cellular and Molecular Life Sciences, 54, 833-850.

Sahandi, M.S. Mehrafarin, A., Badi, H.N., KhalighiSigaroodi, F., Sharifi, M. (2019) Improving growth, phytochemical and antioxidant characteristics of peppermint by phosphate-solubilizing bacteria along with reducing phosphorus fertilizer use. Industrial Crops and Products, 1411, 11777.

Sarker, A., Talukder, N.M., Islam, T. (2014) Phosphate solubilizing bacteria promote growth and enhance nutrient uptake by wheat. Plant Science Today, 1, 86-93.

Selvi, K., Paul, J., Vijaya, V., Saraswathi, K. (2017) Analyzing the efficacy of phosphate solubilizing microorganisms by enrichment culture techniques. Biochemistry and Molecular Biology Journal, 3, 1-7.

Shaheen, H.A., Rabab M. Abd-El-Aziz, R.M., Tawfik, A.E. (2016) Identification and differentiation of Egyptian isolates of Erwinia amylovora using 16S rRNA Gene and RAPD-PCR. Egyptian Journal of Phytopathology, 44, 11-23.

Soumare, A., Boubekri, K., Lyamlouli, K., Hafidi, M., Ouhdouch, Y., Kouisni, L. (2020) From isolation of phosphate solubilizing microbes to their formulation and use as biofertilizers: Status and Needs. Frontiers in Bioengineering and Biotechnology, 7, 1-14.

Suhag, M. (2016) Potential of biofertilizers to replace chemical fertilizers. International Advanced Research Journal in Science, Engineering and 
Technology, 3, 163-167.

Thaller, M.C., Berlutti, F., Schippa, S., Iori, P., Passariello, C., Rossolini, G.M. (1995) Heterogeneous patterns of acid phosphatases containing low-molecular-mass polipeptides in members of the family Enterobacteriaceae. International Journal of Systemic Bacteriology, 4, 255-261.

Tilman, D., Fargione, J., Wolff, B., D'Antonio, C., Dobson, A., Howarth, R., Schindler, D., Schlesinger, WH., Simberloff, D., Wackhamer, D. (2001) Forecasting agriculturally driven global environmental change. Science, 292, 281-284.

Verma, J.P., Yadav, J., Tiwari, K.N., Jaiswal, D.K. (2014) Evaluation of plant growth promoting activities of microbial strains and their effect on growth and yield of chickpea (Cicer arietinum L.) in India. Soil Biology and Biochemistry, 70, 33-37.
Verma, A., Ekka, A. (2017) Effect of nutritional parameters and $\mathrm{NaCl}$ concentration on phosphate solubilization potential of Penicillium purpurogenum Stoll isolated from paddy field. African Journal of Microbiology Research, 11, 356-365.

Yi, Y., Huang, W., Ge, Y. (2008) Exopolysaccharide: a novel important factor in the microbial dissolution of tricalcium phosphate. World Journal of Microbiology and Biotechnology, 24, 1059-1065.

Zaidi, A., Khan, M.S., Ahemad, M., Oves, M., Wani, P.A. (2009) Recent advances in plant growth promotion by phosphate-solubilizing microbes. In: "Microbial Strategies for Crop Improvement", Khan, M.S., Zaidi, A. and Musarrat, J. (Eds.), pp 23-50. Springer-Verlag, Berlin Heidelberg.

\section{كفاءة بكتريا التربة بنطاق الجذور في إذابة الفوسفات و إمكانية استخلا مها كأسمدة

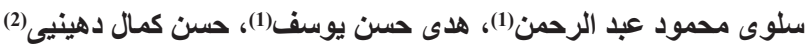

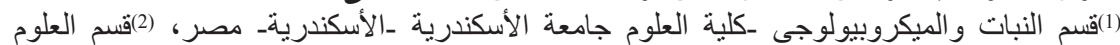
البيولوجية والبيئية ـكلية العلوم جامعة بيروت العية العربيةـ لبنان.

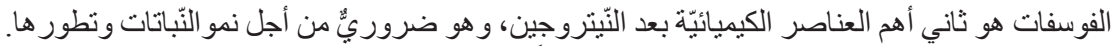

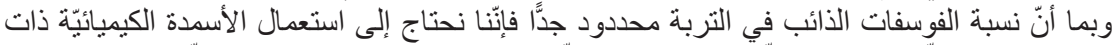

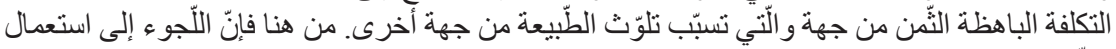

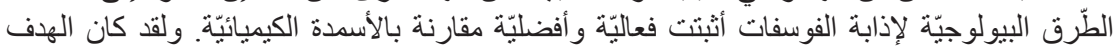

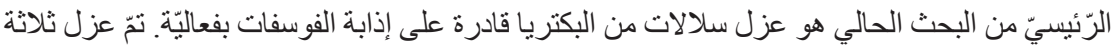

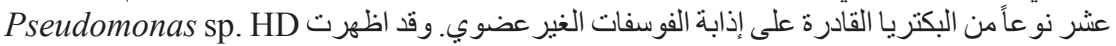

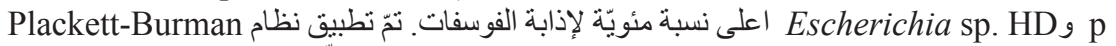

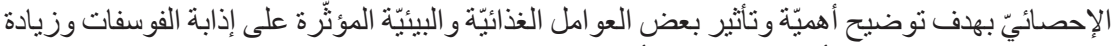

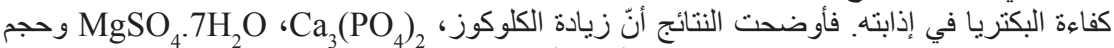

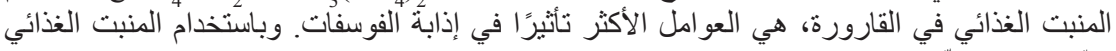

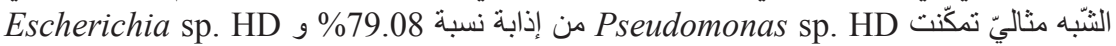

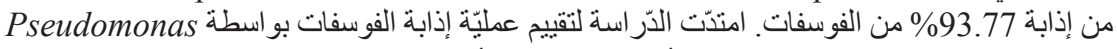

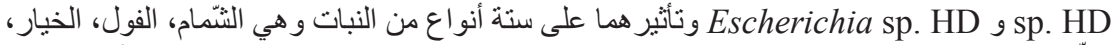

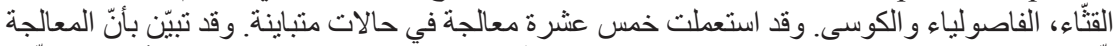

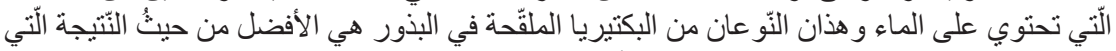

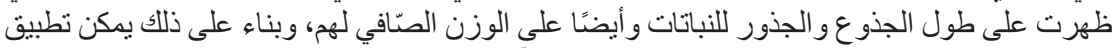

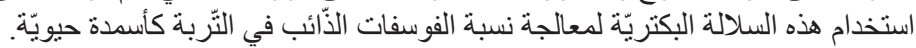

